Plant Tissue Cult. \& Biotech. 20(2): 225-231, 2010 (December)

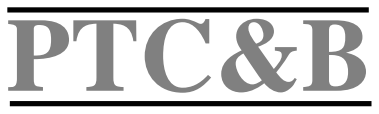

\title{
Micropropagation of Bacopa monnieri using Cyanobacterial Liquid Medium
}

\author{
Meenakshi Banerjee* and Priyanka Modi \\ Laboratory of Algal Biotechnology, Department of Bioscience, Barkatullah University, \\ Bhopal (M.P.), India
}

Key words: Baccopa monnieri, Cyanobacterial extract, Regeneration, Acclimation

\begin{abstract}
Hot extract of Aulosira fertilissima (cyanobacterium) added in different proportions to MS as a liquid culture media for the in vitro propagation of Bacopa monnieri (L.) Pennell. Maximum numbers of shoots were induced from axillary node in MS media $(40 \mathrm{ml})+$ Aulosira extract $(60 \mathrm{ml})$ and maximum shoot multiplication was observed when $\mathrm{Kn}(1.0 \mathrm{mg} / \mathrm{l})$ was added in the shoot initiation media (mentioned above). Surprisingly rooting was also found to be best in the same combination of MS + cyanobacterial extract that was used for initiation and multiplication of shoots. On an average within a period of three subcultures ( 2 - 3 months) the nodal explants generated 400 shoots. Rooted plantlets were successfully transferred to the field, after acclimation in the net house.
\end{abstract}

\section{Introduction}

Heavy exploitation, low propagation response and meager systematic cultivation have resulted in the important medicinal plants becoming extinct and endangered. Very limited studies have been carried out on in vitro conservation of medicinal plants (Handa and Kaul 1996). Plant tissue culture can be considered to involve three phases: (i) The isolation of plant tissue from its usual environment. (ii) The use of aseptic techniques to obtain clean material free of the usual bacterial, fungal, viral and even algal contaminants. (iii) The culture and maintenance of this material in vitro in a strictly controlled physical and chemical environment.

Various compounds of cyanobacteria could be useful sources to enhance or substitute the influenced of synthetic plant growth regulators on tissue cultures of different plants in vitro. The approach of using cyanobacterial cultures would

*Author for correspondence: <banerjeemb@yahoo.co.in, bio_mona04@yahoo.co.in> 
overcome many barriers of micropropagation were costly synthetic chemicals involved (Banerjee and Sarkar 2008). The in vitro propagated medicinal plants furnish a ready source of uniform, sterile on and compatible plant material for biochemical characterization and identification of active constituent (Banerjee and Shrivastava 2008). Recently in a report by the National Medicinal Plant Board (NMPB), Government of India and Technology Information Forecasting and Assessment Council (TIFAC) has recommended immediate attention to few medicinal plants, among which Bacopa monnieri prominently features, which makes this plant in the category of highly endangered plants in India (http//www.nmpb.nic,in/prioritisedmedicinalplants.htm). Bacopa monnieri (L.) Pennell under the family scrophulariaceae is commonly known in India as 'Brahmi' is an ancient and renowned medicinal plant with legendary reputation as memory vitalizer. Brahmi is found to be effective in case of anxiety and neurosis (Bafna and Balaraman 2005). It possesses anti-inflamatory, analgesic and antipyretic activity (Agrawal 1993). It is also used to treat asthma, insanity, epilepsy, hoarseness, and enlargement of the spleen, snake bite, rheumatism, leprosy, eczema, ring worm, diuretic, aperitive and cordiotonic. The plant nervine activity of Bacopa monnieri has been attributed due to presence of saponin such as bacopside A, B, C and D (Rastogi et al. 1994, Sinha and Saxena 2006). The plant also contains several alkaloids, such as, nicotine, brahmin, herpestine, several other chemical like stigmastenol, stigmesterol and b-sitosterol (Shrivastava and Rajani 1999).

The present paper deals with the use of cyanobacterial extract as a liquid culture media for the induction and multiplication of adventitious shoot bud to ensure high yield of biomass of this medicinal herb. This protocol is very cost effective and totally novel where liquid culture of cyanobacterial extract have been used for the efficient regeneration of Bacopa monnieri.

\section{Material and Methods}

Stock culture of Aulosira fertilissima species were taken from the culture collection of Algal biotechnology laboratory, Department of Biosciences, Barkatullah University, Bhopal and grown in BG-11 free nitrogen medium (Rippka et al. 1979). Isolation and purification of cultures were carried out using the techniques adopted by (Vekataraman 1969). Identification of maintained axenic cyanobacteria was carried out according to (Desikarchary 1959) and (Whiteford and Schumacher 1973). The isolated organisms were batch cultured (100 ml) was grown in Erlenmeyer flask $(250 \mathrm{ml})$ and tissue culture was initiated with inoculation of 7 days old blue green algal cultures. The cultures were incubated at $28^{\circ} \mathrm{C} \pm 1$ at light intensity of about 2500 to 3000 luxs. The cyanobacterial culture 
was harvested in the early stationary phase of growth by vigorously shaking by sterilized glass beads for $15 \mathrm{~min}$.

Nodal explants $(1.5 \mathrm{~cm})$ were isolated from 2 - 3 month-old-plants (before flowering) growing in the medicinal plant nursery of Bhopal. The explants were washed thoroughly, first under running tap water for $20 \mathrm{~min}$ to remove adherent particles, then treated with a liquid detergent labolene (5\% v/v) for $15 \mathrm{~min}$ followed by washing in tap water and rinsed five times with double distilled water. These were surface disinfected for $4 \mathrm{~min}$ in $0.1(\mathrm{w} / \mathrm{v}) \mathrm{HgCl}_{2}$ followed by repeated washes with sterile double distilled water and cultured on GR free MS containing $3 \%(\mathrm{w} / \mathrm{v})$ sucrose and $0.8 \%(\mathrm{w} / \mathrm{v})$ agar. The axillary buds of nodal explants began to grow within 3 - 4 days of culture with one of the two buds present on node developed in to an axillary shoot, while the other bud showed only limited growth. When the axillary branches were $5-6$ c.m long they were excised and cut in to 1 - 2 segments, each of which were transferred to GR free MS medium. These cultures served as a stock culture and were the sources of explants for different experiments. The stock cultures were maintained on GR free MS medium node cultures. (Tiwari et al. 1998).

Healthy nodal explants $(0.9 \mathrm{~cm})$ were excised from six week old in vitro cultures raised as described above.

MS supplemented with $\mathrm{CaCl}_{2}(0.44 \mathrm{gm} / \mathrm{l}), 3 \%(\mathrm{w} / \mathrm{v})$ sucrose, cyanobacterial extract (Aulosira fertilissima) was used in this experiment. The $\mathrm{pH}$ of the medium was adjusted to 5.8. The culture vials containing the media were autoclaved at $121^{\circ} \mathrm{C}$ at $15 \mathrm{lbs}$ pressure for $20 \mathrm{~min}$. All the cultures were maintained at $24 \pm 2^{\circ} \mathrm{C}$ under $16 \mathrm{hr}$ photoperiods and $8 \mathrm{hr}$ dark periods with a photosynthetic photon flux density (PPFD) of $50 \mu \mathrm{mol} \mathrm{m} / \mathrm{s}$ provided by cool white fluorescent lamps (Phillips, India) and with 50 - 55\% relative humidity.

Cyanobacterial culture in the text means equal volume $(60 \mathrm{ml})$ of cyanobacterial liquid cultures mentioned above centrifuged. Hot extract was made by adding $100 \mathrm{ml}$ of autoclaved distilled water and from this $10-100 \mathrm{ml}$ hot extract was taken for initiation and maturation medium respectively with added MS, sucrose and $\mathrm{CaCl}_{2}$ only.

Hot extract of cyanobacterial species, Aulosira fertilissima (10 - $90 \mathrm{ml})+\mathrm{MS}(10$ - $90 \mathrm{ml})+$ sucrose $3 \%(\mathrm{~W} / \mathrm{v})+\mathrm{CaCl}_{2}(0.44 \mathrm{gm})$. Hot extract of cyanobacterial species, Aulosira fertilissima $(10-90 \mathrm{ml})+\mathrm{MS}(10-90 \mathrm{ml})+\mathrm{Kn}(1.0 \mathrm{mg} / \mathrm{l})+$ sucrose $3 \%(\mathrm{w} / \mathrm{v})+\mathrm{CaCl}_{2}(0.44 \mathrm{gm})$.

Rooting was found to be best in that combination which was used for initiation and multiplication media. Rooted microshoots were removed from culture vessels and after washing the root gently under running tap water, the plantlets were placed in to plastic cups filled with garden soil, mixed with vermiculite and sand $(1: 1: 1)$. The cups filled with polythene bags and irrigated 
daily with $9-10 \mathrm{ml}$ of tap water; the plants were maintained under controlled growth chamber conditions $\left(24 \pm 2^{\circ} \mathrm{C}\right)$ and $50-55 \%$ relative humidity. Polythene bags were opened after two weeks in order to acclimatize plants to field conditions. After two weeks, acclimatized plants were transferred to pots containing normal garden soil and maintained in a green house under natural light.

\section{Result and Discussion}

The authors have studied the effect of hot cyanobacterial extract and MS on shoot induction on Bacopa monnieri for rapid and large-scale multiplication at a cost effective level (Table 1). Explants remained green and fresh but failed to grow any further in growth regulator free medium that is control. The combined effect of cyanobacterial extract $(60 \mathrm{ml})$ and MS $(40 \mathrm{ml})$ proved optimal for maximum shoot proliferation showing 20 shoots per explant with 9.2 shoot length over

Table 1. Effect of different ratio of cyanobacterial extract (CE) (Aulosira fertilissima) and MS on in vitro shoot proliferation from nodal segment of Bacopa monnieri. (After two week)

\begin{tabular}{ccccc}
\hline Sl. No. & MS + CE & $\begin{array}{c}\text { Shoot } \\
\text { number }\end{array}$ & $\begin{array}{c}\text { Shoot } \\
\text { length }\end{array}$ & $\begin{array}{c}\text { Survival rate } \\
(\%)\end{array}$ \\
\hline 1. & Control & - & $0.9 \pm 0.7$ & 0 \\
2. & $\mathrm{MS}(10 \mathrm{ml})+\mathrm{CE}(90 \mathrm{ml})$ & $16 \pm 2.25$ & $7.5 \pm 2.0$ & 97 \\
3. & $\mathrm{MS}(20 \mathrm{ml})+\mathrm{CE}(80 \mathrm{ml})$ & $10 \pm 1.75$ & $2.8 \pm 1.3$ & 75 \\
4. & $\mathrm{MS}(30 \mathrm{ml})+\mathrm{CE}(70 \mathrm{ml})$ & $18 \pm 2.79$ & $7.9 \pm 2.12$ & 99 \\
5. & $\mathrm{MS}(40 \mathrm{ml})+\mathrm{CE}(60 \mathrm{ml})$ & $20 \pm 2.95$ & $9.2 \pm 2.32$ & 100 \\
6. & $\mathrm{MS}(50 \mathrm{ml})+\mathrm{CE}(50 \mathrm{ml})$ & $15 \pm 2.19$ & $6.0 \pm 1.89$ & 95 \\
7. & $\mathrm{MS}(60 \mathrm{ml})+\mathrm{CE}(40 \mathrm{ml})$ & $9 \pm 1.42$ & $2.2 \pm 1.29$ & 70 \\
8. & $\mathrm{MS}(70 \mathrm{ml})+\mathrm{CE}(30 \mathrm{ml})$ & $12 \pm 1.88$ & $3.0 \pm 1.52$ & 80 \\
9. & $\mathrm{MS}(80 \mathrm{ml})+\mathrm{CE}(20 \mathrm{ml})$ & $8 \pm 1.29$ & $1.9 \pm 1.17$ & 50 \\
10. & $\mathrm{MS}(90 \mathrm{ml})+\mathrm{CE}(10 \mathrm{ml})$ & $13 \pm 2.0$ & $5.2 \pm 1.63$ & 87 \\
\hline
\end{tabular}

Value are mean \pm standard error of three replicates with ten cultures per replicates; data scored after three week. $\mathrm{CE}=$ Cyanobacterial Extract. Explants remained green and fresh but failed to grow any further in growth regulator free medium that is control.

the control ( $p<0.01$, Fig. 1). Shoot multiplica-tion was observed when Kn (0.25 $2.25 \mathrm{ml}$ ) was added in the shoot initiation media (cyanobacterial extract and MS). The best combination was found to be the cyanobacterial extract $(60 \mathrm{ml})+\mathrm{MS}(40$ $\mathrm{ml})$ with the concentration of $\mathrm{Kn}(1 \mathrm{ml})$ (Table 2, Fig. 2). This combination showed the record number of 56 shoots with the average length $15.5 \mathrm{~cm}$. The maximum frequency of root formation $(100 \%)$, number of roots (15) and root length $(4.0 \mathrm{~cm})$ was achieved in MS $(40 \mathrm{ml} / \mathrm{l})+$ cyanobacterial extract $(60 \mathrm{ml} / \mathrm{l})$ (Table 3, Fig. 2). 
Efficient and cost effective micropropagation of Bacopa monnieri employing liquid medium has been achieved. In the case of employing liquid medium; while on the one hand lesser amount of medium is consumed, on the other hand, shoot growth and multiplication response were better than in solid medium. The most commonly using gelling agent - agar (adding up to 65\% of the cost of the culture medium) results in local accumulation of heat and hinders the access of
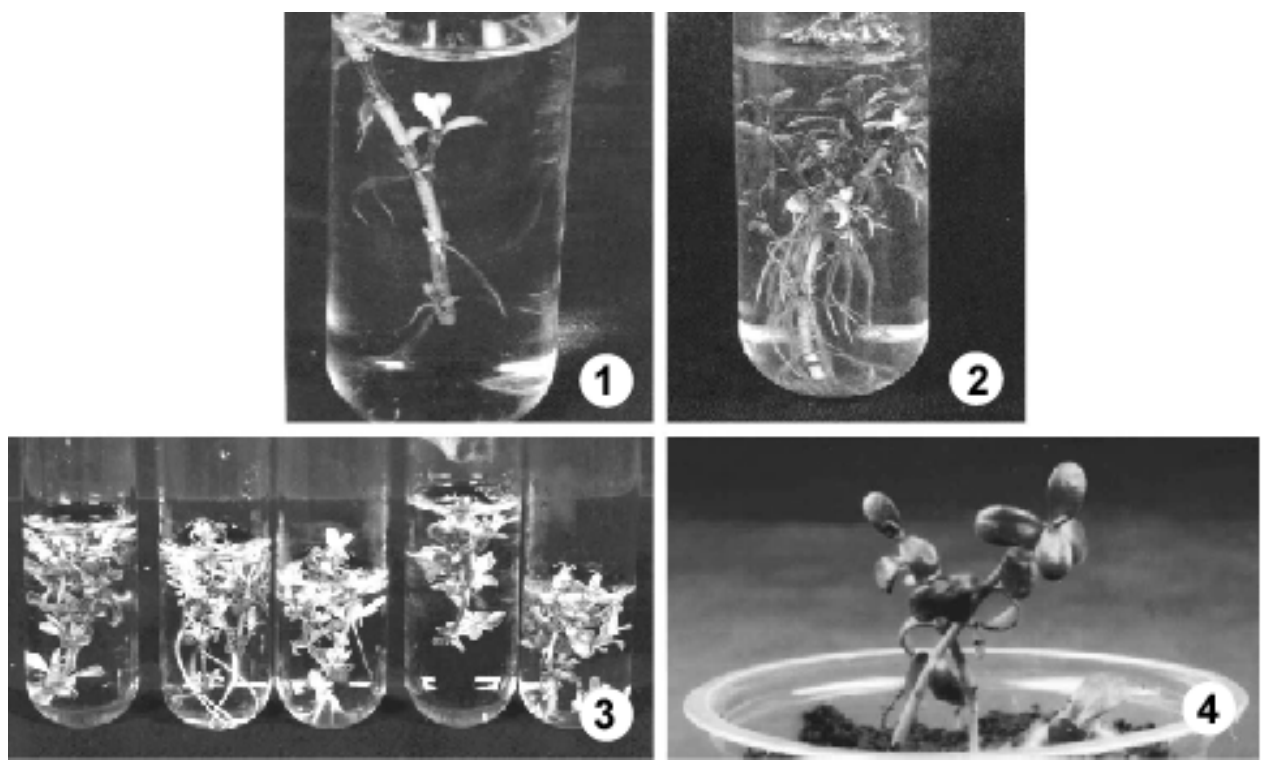

Figs 1 - 4: 1. Initiation of shoots and roots in Brahmi (after two week). 2. Elongation and multiplication of shoots and roots (After four week). 3. Series of test tube showing multiplication of shoots and rooting in same media. 4. An acclimatized plant in pot.

Table 2. Effect of $\mathrm{Kn}$ on the multiplication of shoots of Bacopa monnieri. (after four weeks)

\begin{tabular}{ccccc}
\hline $\begin{array}{c}\text { Sl. } \\
\text { No. }\end{array}$ & \begin{tabular}{c} 
MS $+\mathrm{CE}+\begin{array}{c}\text { growth regulator } \\
(\mathrm{mg} / \mathrm{l})\end{array}$ \\
\hline 1.
\end{tabular} & $\begin{array}{c}\text { Shoot } \\
\text { number }\end{array}$ & $\begin{array}{c}\text { Shoot length } \\
(\mathrm{cm})\end{array}$ & $\begin{array}{c}\text { Survival } \\
\text { rate }(\%)\end{array}$ \\
\hline
\end{tabular}

Value are mean \pm standard error of three replicates with ten cultures per replicates; data scored after three weeks.

dissolved oxygen to culture cells. By employing to liquid culture medium, reduction in plant production cost can be achieved. There is accumulating evidence that some of the hormones which operate in higher plants could have similar role in cyanobacteria. The effect of cyanobacterial extract was tested on growth and multiplication of shoots from shoot tips. Cyanobacterial media showed primitive effect on shoot multiplication. Higher cyanobacterial 
concentration exhibited increase frequency of multiple shoot formation and shoot growth compared to MS. Though all the components of MS medium were effect the shoot multiplication, rooting and regeneration of plantlets. These alteration in the medium would be useful in lowering the total cost of tissue cultured Brahmi without affecting the rate of multiplication and quality of plants. The rooted plantlets were successfully harden off inside the growth room in sterile soil rite for two weeks and eventually established in natural soil. There

Table 3. Effect of different ratio of cyanobacterial extract (Aulosira fertilissima) and MS on adventitious root formation in Bacopa monnieri. (after two weeks)

\begin{tabular}{ccccc}
\hline $\begin{array}{c}\text { Sl. } \\
\text { No. }\end{array}$ & MS + CE & $\begin{array}{c}\text { Root } \\
\text { number }\end{array}$ & $\begin{array}{c}\text { Root } \\
\text { length }(\mathrm{cm})\end{array}$ & $\begin{array}{c}\text { Survival rate } \\
(\%)\end{array}$ \\
\hline 1. & Control & - & $0.5 \pm 0.01$ & 0 \\
2. & $\mathrm{MS}(10 \mathrm{ml})+\mathrm{CE}(90 \mathrm{ml})$ & $10 \pm 1.63$ & $3.2 \pm 1.09$ & 97 \\
3. & $\mathrm{MS}(20 \mathrm{ml})+\mathrm{CE}(80 \mathrm{ml})$ & $4 \pm 0.78$ & $1.8 \pm 0.52$ & 75 \\
4. & $\mathrm{MS}(30 \mathrm{ml})+\mathrm{CE}(70 \mathrm{ml})$ & $12 \pm 2.00$ & $3.5 \pm 1.75$ & 99 \\
5. & $\mathrm{MS}(40 \mathrm{ml})+\mathrm{CE}(60 \mathrm{ml})$ & $15 \pm 2.20$ & $4.0 \pm 1.99$ & 100 \\
6. & $\mathrm{MS}(50 \mathrm{ml})+\mathrm{CE}(50 \mathrm{ml})$ & $9 \pm 1.32$ & $2.9 \pm 0.88$ & 95 \\
7. & $\mathrm{MS}(60 \mathrm{ml})+\mathrm{CE}(40 \mathrm{ml})$ & $3 \pm 0.57$ & $1.5 \pm 0.34$ & 70 \\
8. & $\mathrm{MS}(70 \mathrm{ml})+\mathrm{CE}(30 \mathrm{ml})$ & $5 \pm 0.99$ & $2.0 \pm 0.65$ & 80 \\
9. & $\mathrm{MS}(80 \mathrm{ml})+\mathrm{CE}(20 \mathrm{ml})$ & $2 \pm 0.32$ & $1.0 \pm 0.20$ & 50 \\
10. & $\mathrm{MS}(90 \mathrm{ml})+\mathrm{CE}(10 \mathrm{ml})$ & $7 \pm 0.22$ & $2.3 \pm 0.72$ & 87 \\
\hline
\end{tabular}

Value are mean \pm standard error of three replicates with ten cultures per replicates; data scored after three weeks.

was no detectable variation among the potted plants with respect to morphological and growth characteristics. The protocol described here is a novel approach to regenerate Brahmi instead of use of agar, cost effective and ecofriendly. Thus due to higher response of shoot growth and multiplication, liquid culture medium can be useful for large scale multiplication of Bacopa monnieri.

\section{Acknowledgements}

Bioscience Department, Barkatullah University, Bhopal (M.P), supported the work in the author's laboratory.

\section{References}

Agrawal A (1993) A comparative study of psychotropic drugs and bio-feedback therapy in the prevention and management of psychosomatic disorders. A Ph.D. Thesis (Banaras Hindu University), Varanasi, India. 
Bafna PA and Balaraman R (2005) Antioxidant activity of DHC-1, an herbal formulation, in experimentally induced cardiac and renal damage. Phytother. Res. 19(3): 216-221.

Banerjee $\mathbf{M}$ and Sarkar $\mathbf{P}$ (2008) In vitro callusing in Stevia rebaudiana Bertoni using cyanobacterial media - a novel approach to tissue culture. IJIB. 3: 163.

Banerjee $\mathbf{M}$ and Shrivastava S (2008) An improved protocol for in vitro multiplication of Bacopa monnieri (L.). World J. Micro. and Biotech. 24:1355-1359.

Desikachary TV (1959) Cyanophyta; Indian Council of Agricultural Research, New Delhi.

Handa SS and Kaul MK (1996) Supplement to cultivation and utilization of medicinal plants. Regional Research Laboratory, CSIR, Jammutawi.

Rastogi S, Mehrotra BN and Kulshreshtha DK (1994) In: Deep publications (Ed) proceedings of IV International Congress of Ethnobiology, New Delhi, p. 93.

Rippka RJ, Deruelles JB, Waterburg M, Herdman and Stanier RY (1979) Generic assignments, strain histories and properties of pure cultures of cyanobacteria. J. General Microbiol. 111:1-16.

Sinha S and Saxena R (2006) Effect of iron on lipid peroxidation and enzymatic and nonenzymatic antioxidents and bacoside - a content in medicinal plant Baccopa monnieri L. Chemosphere 62:1340-1350.

Shrivastava N and Rajani M (1999) Multiple shoot regeneration and tissue culture studies on Bacopa monnieri (L.) Pennel. Plant cell Reports.18: 919-923.

Tiwari V, Singh BD and Tiwari KN (1998) Shoot regeneration and somatic embryogenesis from different explants of Brahmi [Bacopa monnieria (L.) Wettest. ]. Plant Cell Reports.

Venkataraman GS (1969) The cultivation of algae. Published by Indian Council of Agricuture research, New Delhi, 319.

Whiteford LA and Schumacher GJ (1973) A manual of fresh-water algae. Published by Sparks press. Releigh, N C. 